\title{
The Prodigal Sons of Africa Proselytized to Christianity: Cultural Renegades and Apostates in Achebe's Novels
}

\author{
Virender Pal \\ Department of English, University College Kurukshetra. ORCID: oooo-0oo3-3569-1289. \\ Email:pzvicky@gmail.com
}

Received January 11, 2017; Revised March 15, 2018; Accepted March 25, 2018; Published May o7, 2018.

\begin{abstract}
In the postcolonial world the literary writers and postcolonial theorists have made immense contributions to piercing through the veil of the policies of colonialism. While the theories of the theorists written by Colonialism remain and are read and understood by a privileged few, literature is read by people across all the cultures and nationalities. Chinua Achebe is one of the most important name among such writers who have contributed immensely to postcolonial studies. His novels show that colonialism was an enterprise to plunder the natural resources of the enslaved countries in the name of spreading the light of civilization. This spreading of light of civilization lead to the annihilation of local cultures as the local cultures were systematically obliterated and replaced with the alien white culture. His first novel Things Fall Apart was written as a reply to Conrad's Heart of Darkness. The novel asserted that Africa was civilized before the arrival of the whites. In No Longer at Ease (1960) he studies the impact of sustained colonial rule on his people. The current paper is a study of Chinua Achebe's novel No Longer at Ease and Things Fall Apart. The novesl shows that the indigenous culture and religion was the best for the Africans. The imposition of an alien culture has created intractable problems for the Nigerians and the remedy lies only in going back to the roots, to the Ibo "commonsense."
\end{abstract}

Keywords: colonialism, Christianity, Ibo, Africa, corruption.

In the last century many critiques of colonialism were published. Theorists like Frantz Fanon, Aime Cesaire, Albert Memmi and others pierced through the veil of colonialism and its policies and deciphered it for the common people. Creative writers also played their part in demystifying the colonial enterprises. They wrote novels, plays and poems about how the colonial juggernaut worked and what were the aims of colonialism. The colonial narratives published by the whites were immersed in racist bias and the natives were represented as cannibals and barbarians. The depictions were important because the Europeans wanted to "scramble for Africa" and this scramble resulted in "perennial infestation of little tyrants and tin-pot megalomaniacs spread all over Africa propagating internecine bloodbaths whose purpose is, and always has been, not only to unearth and annihilate all manifestation of dissent but to divide and plunder" (Bandele, 2001, p. ix).

Africans were voiceless at that time as they could not read what was written about them and they could also not write back. The African culture was largely oral; without a script; though this does not mean that their language was less complex when compared to European languages. The most potent voice against this misrepresentation was heard in 1958 with the publication of

(c) AesthetixMS 2018. This Open Access article is published under a Creative Commons Attribution Non-Commercial 4.0 International License (http://creativecommons.org/licenses/by-nc/4.o/), which permits non-commercial re-use, distribution, and reproduction in any medium, provided the original work is properly cited. For citation use the DOI. For commercial re-use, please contact editor@rupkatha.com. 
Chinua Achebe's Things Fall Apart. His contribution to the development of African literature can be understood from the fact that he has been called "the person who invented African literature" (Gikandi, 2001, p. 5). In his first novel Achebe studied the consequences of contact between his people and the whites. At the same time, the novel made it clear that the Africans were not uncivilized as depicted by the colonial narratives. In the second novel No Longer at Ease he studied the impact of colonialism on his people.

Things Fall Apart was really the game changer in the field of African studies. The novel changed the perception of the Africans. A teacher reported that her students after reading the novel realized that the Africans were not savages as portrayed by the colonial narratives and they did not live in mud huts in the forest. The novel also inspired the students to engage in a discussion about moral issues of colonialism (Merriam, 1988, p. 67). No Longer at Ease failed to replicate the success of Things Fall Apart. Many of the readers ignored it because they regarded "it as somehow less objective than other works by the writer on the recurring theme of colonialism in Nigeria" (Babalola, 1986, p. 139). While Things Fall Apart depicted the confusion and chaos created by the arrival of the whites in Ibo World; No Longer at Ease depicts the changes that have come in the Ibo people due to the imposition of colonialism and the white culture of which Christianity is the most important ingredient.

No Longer at Ease depicts the changes that have taken place in the Ibo society through Obi Okonkwo, the grandson of Ogbuefi Okonkwo; the great warrior whose story is at the heart of Things Fall Apart. Obi is the son of Isaac Okonkwo (Nwoye) who converted to Christianity during the life time of his father and was abandoned by him. Comparison of Obi with his grandfather shows how 'de-culturation' has changed the characteristics of a race.

There is a strong physical resemblance between the two: on seeing Obi tribal elder Odogwu remarks, "He is Ogbuefi Okonkwo come back. He is Okonkwo. Kpom- kwem, exact, perfect" (NLE, 2010, p. 43), but the similarity between the two ends here. Ogbuefi Okonkwo was a man of action who was not a good orator. In fact "he had a slight stammer and whenever he was angry and could not get his words out quickly enough, he would use his fists" (TFA, 2001, p. 1). On the other hand, Obi is a man of words only and no action. His mind has been conditioned by his "mission house upbringing and European education" (NLE, 2010, p. 71). This Obi Okonkwo is a de-cultured person whose personality has been shaped by the colonial institutions. In this regard Babalola rightly comments about Obi that he is "an archetype of the contemporary Blackman in search of ease in European life style that is fast altering his cultural setting" (140).

Achebe stresses that Obi's tragedy is a tragedy of de-culturation. The Blackman was shorn of his culture and an alien culture was thrust on him. The imposition of alien culture created problems for the blackman. No culture in the universe can claim to be a universal culture. There are certain elements that are common to all the cultures, but the key ingredients of a culture depend on local geography and climate. So it was a mistake on the part of the white man to impose European culture on the Africans. While defining culture Roger M. Keesing points out:

Cultures are systems (of socially transmitted behavior patterns) that serve to relate human communities to their ecological settings. These ways- of- life- of- communities include technologies and modes of economic organization, settlement patterns, modes of social grouping and political organization, religious beliefs and practices, and soon. When cultures are viewed broadly as behavior systems characteristic of populations, extending and permuting somatic givens, whether we consider them to be patterns of or patterns for behaviors is a secondary question. (1974, p.75) 
In the above definition culture is defined as a link between the human beings and their "ecological settings." The ecology in Nigeria was totally different from that of Britain so the culture that evolved in both the places was drastically different, but the whites under the impression of their racial superiority did not pay any attention to the relation between geography of a place and the culture. For them the European culture was the only worth following; everything else was a deviation.

Now because the Africans followed a deviant culture it implied that their civilization was also inferior. In fact the whites acknowledged that the Africans had developed some sort of culture; but they were not convinced about the development of civilization in Africa. The whites believed that culture and civilization could only develop in cold places like Europe. Warmer places like Africa and Asia were incapable of hosting a civilization and nurturing an ideal culture. That is why Mr. Green, the English Boss of Obi, says that all the Africans are corrupt (NLE, 2010, p. 3).The reason that is offered by Mr. Green for the corrupt nature of Africans makes clear the European bias: "The fact that over countless centuries the African has been the victim of the worst climate in the world and of every imaginable disease. Hardly his fault. But he has been sapped mentally and physically. We have brought him Western Education" (2010, p.3).

The above lines make clear that Africans could not cultivate high ideas of civilization because of the "worst climate." The comment shows the irrationality of the white man and how arbitrary and illogical associations were formed about the blacks while the whites had pretensions to reason, rationality and logic. However, it must be noted that the theory of relationship between climate and civilization was not developed by Achebe, rather it was developed by the white man himself. In the traveller literature written by the whites "often a connection is made between the intellectual and psychological prowess of a people and the climate of the land they inhabit" (Balagangadhara, 2013, p. 69). Now because the whites themselves lived in cold climate so they were convinced that all the people who were living in such climate were civilized, while the people who were living in hotter climate were savages. For illustration consider the following paragraph about Tibet, a cold region in Asia:

The kingdom of TRIMIC is all surrounded by mountains which give rise to many fountains and lives. This land has a very healthy climate and agubilada so that those who are born and live here have very long lives. They are men of clear understandings and good memories, learned in sciences and live according to law. They say that the men who first heard of science and learning were these and that Persians heard of those things from them. This is because they are at birthplace of the east and the rest of the towns and great cities and the root of this kingdom are all due to the temperate climate which tempered their bodies and the good extended to their spirits and gave them better understandings and clearer memories. (Espada, 1877, p. 49)

The relationship between "temperate climate" and "intellectual prowess" is clear from the above passage. Similar claim was made by Gourou in his book Les Pays Tropicaux. In the book, he claimed that "there has never been a great tropical civilization, the great civilizations have existed only in temperate climates, that in every tropical country the germ of civilization comes, and can only come, from some other place outside the tropics" (qtd. in Cesaire, 2010, p. 55).

Thus, imperialism in Nigeria was an attempt to plant and nurture a civilization (as a subterfuge because the imperialism was synonymous to plunder of natural resources) because Nigeria being a tropical country could not nurture one. But this planting of an alien civilization had disastrous consequences for the people. The most important drawback of a planting an alien 
civilization was wide spread corruption among the Nigerians. Corruption and money were unknown to the Nigerians before the arrival of the whites. Amos Tutolas's novel The Palm Wine Drinkard makes a point about this:

I was a palm wine drinkard since I was a boy of ten years of age. I had no other work more than to drink palm-wine in my life. In those days we did not know other money, except cowries, so that everything was very cheap, and my father was richest man in our town. (1952, p.1)

The changes came in the society with the arrival of the whites. The whites disrupted the traditional life style of the Nigerians. Aime Cesaire in his treatise Discourse on Colonialism has revealed this aspect of colonialism:

I am talking about natural economies that have been disrupted - harmonious and viable economies adapted to the indigenous population - about food crops destroyed, malnutrition development oriented solely toward the benefit of the metropolitan countries; about the looting of products, the looting of raw materials. (2010, p.3)

The economies in these countries were barter economies where everybody had something to exchange for the things they needed. Prestige in this society had nothing to do with money; rather it was based on one's bravery and hard work. Everything in this society was cheap and within the reach of everybody, but the arrival of whites and their trading practices changed everything: "He had also built a trading store and for the first time palm- oil and kernel became things of great price and much money flowed into Umuofia” (TFA, 2001, p. 130).

The introduction of money and alien trade practices laid the foundation of tragedy in No Longer at Ease. The novel shows what de-culturation can do to people. Nigerian society in No Longer at Ease is riddled with corruption (2010, p.3, 15, 16, 25 and 31). This brings the reader back to the issue of corruption as/ is a result of de-culturation that took place in Nigeria during the colonial rule. This is evident in the character of Obi who is alienated from his family and kinsmen due to his Western education and Christian upbringing.

The Ibo life was rooted in community where every person felt for the other person compared to the rugged individualism of the whites. So while imposing their culture on the Nigerians, the whites broke the tribal affinities of the Ibo people and the job was accomplished by the "lunatic religion" (TFA, 2001, p. 130) of the whites. The novel proves that the most important and potent weapon of the white man was not fire arms, rather it was the religion of the white man. Introduction of Christianity among the Ibos shook the foundations of the society.

The people who converted to Christianity started proclaiming that the traditional customs followed by them in pre-Christian life were satanic (TFA, 2001, p. 129). The whites convinced the Ibos that their religion was satanic, so the people who converted to Christianity started believing that they had received the truth, but this accentuated their biases against their countrymen who were believed to be "people of nothing" (NLE, 2010, p. 47). The converts started believing that they were superior to the others and a permanent division was created in the society. The converted people sing a song in which they themselves admit that they were backward:

The people which sat in darkness.

Saw a great light,

And to them which sat in the region and shadow of death.

To them did light spring up. (NLE, 2010, p. 7) 
Thus, conversion to Christianity means to start the process of de-culturation, to start despising the customs and traditions followed by ancestors, to start abhorring the people who have not converted and to start hating everything which is not associated with newly acquired faith. This happens with Obi also. He is alienated from other people who have not converted. Obi tells how his mother taught him to differentiate between Christians and heathens:

She told her children not to accept food in neighbors' houses because she said they offered their food to idols. That fact alone set her children apart from all others for, among the Ibo, children were free to eat where they liked. (NLE, 2010, p.46)

The folk stories of Ibo culture are also banned from the house. Obi's father tells them: "We are not heathens. Stories like that are not for the people of Church" (p. 46). Whatever Achebe writes about Christianity has been observed throughout the world:

At the same time, underlying all the rationalizations and justifications for the Europeans' presence was the belief that as Christians they and they alone had the truth. This had justified the astonishing excesses of the crusades against infidel Islam, centuries of antiSemitism and with the discovery of native populations on other continents, a missionary zeal that justified any kind of violence seen to be needed, since by definition such people were mentally and culturally below par, not being Christian - the colonial version of a catch 22. This underlying attitude about Christianity infused and justified all other actions in the new world, and would so well into the twentieth century. After the ravages of European - borne diseases, the religion of the Europeans was the single most dangerous force the Indians across the entire hemisphere would ever face. (Page, 2003, p. 111)

The above quotation has been made by Jake Page about the natives of America, but it is applicable to Africa also.

Chinua Achebe makes clear that conversion to Christianity means alienation among his own people and in some extreme cases the converted people even became enemies of their people (TFA, 2001, p. 136). However, it must be made clear that hatred and enmity is only from the side of converts, the Ibos following traditional beliefs did not profess such hatred towards the newly converted Christians. In fact, the people following traditional beliefs were ready to assimilate with the converted Christians. Achebe makes it clear with the response of Ogbuefi Odegwu, the tribal elder, to Obi's father's objection. Obi's father being a Christian makes clear that "heathen sacrifice" (NLE, 2010, p. 41) will not take place in house, but the tribal elder tries to take a middle path and offers to break Kola nut in "the Christian way" (NLE, 2010, p. 41). He also says the prayers in a Christian way:

'Bless this Kola nut to that when we eat it, it will be good in our body in the name of Jesu Kristi. As it was in the beginning it will be at the end. Amen. (NLA, 2010, p.42)

Thus, the Ibo people following traditional beliefs do not find any conflict between their beliefs and Christianity. It is the imposed imported religion that leads to alienation of the converts. Chinua Achebe makes clear that the traditional Ibo people have a better understanding of metaphysics. Tribal elder Akunna's conversation with the missionary Mr. Brown makes this clear. Akunna makes clear that God is indeed one, only they call Him with different names: "You say there is one supreme God who made heaven and earth. We also believe in Him and call Him chukwu. He made all the world and the other Gods" (TFA, 2001, p. 131). 
On the other hand, the Christians who believe in one God are deeply divided people. The division between Roman Catholics and Protestants are clear from the derogatory song sung by the Protestant children:

Palm fruit eater, Roman Catholic teacher,

His misses a devourer of toads. (NLE, 2010, p. 40)

Compared to these Ibo traditions were syncretic. Achebe himself tells in an interview:

The Ibo's religion did not fully understand the nature of Christianity. Even the next village has a different God, so they must have theirs. They simply thought this was another of the same kind, but they were mistaken because this was a totalitarian religion we used to talk about. The way, The Truth and The Light. But I think, in the end, Ibo commonsense prevailed after the initial clashes. (Bonneti, 1989, p. 77)

Prevailing of the "Ibo commonsense" shows that Achebe was convinced of the wisdom of his people, their plural ethos and hence their superiority. Amid this conflict between Christianity and traditional beliefs it is clear that Achebe's sympathies lie with Ibo religion. He further clarifies:

Earlier though there was more tension that was handled very well, I think, because our people are generally moderate... It seemed to have been fairly accommodating kind of culture. To them it was just another concession here and there. (1989, p.76)

Achebe's convictions about Ibo religion are clear in the novels also. The Ibo Gods are called "Gods of deceit" (TFA, 2001, p. 107) by the missionaries, but Achebe rebuts this claim. Consider this incidence from No Longer at Ease for instance where the people have gathered to celebrate Obi's return to his village. Obi's father refuses to "take palm-wine, a cock and a little money to the chief rain maker of Umuofia" (39) because "Christianity had made him blind" (38). The elders are sure that this blasphemous act of Isaac Okonkwo will make the "chief rain maker of Umuofia" angry and it will rain heavily. The rain does fall and it is "unusual" (50) which proves that elders were correct about the rain God.

Christianity not only severs the ties with the community, but it is also responsible for severing the ties of family members. It is ironical that Christianity estranged Obi's father to his father (TFA, 2001, p. 111). It also estranges Obi to his father in No Longer at Ease. Christianity certainly changes the attitudes of people, but it does not make any change in the social status of the people. In Things Fall Apart, Achebe made it clear that Christianity thrived on the low-born and the outcastes (TFA, 2001, p. 127), but their social status does not undergo any change. Obi wants to marry an Osu (an outcaste), a girl called Clara and justifies that they are Christians so they should not have any objection:

Our fathers in their darkness and ignorance called an innocent man Osu, a thing given to idols and there after he becomes an outcast, and his children forever. But have we not seen the light of the Gospel? (NLE, 2010, 106)

All the arguments of Obi fail to impress his father. He has become a Christian but his Ibo beliefs regarding outcastes have not changed. He tells Obi:

Osu is like leprosy in the minds of our people. I beg of you, my son, not to bring the mark of shame and leprosy into family. If you do, your children and your children's children unto the third and fourth generations will curse your memory. It is not for myself I speak my days are few. You will bring sorrow on your head and on the heads of your children. (NLE, 2010, p. 107) 
However, this bias was not restricted to the native Nigerians only, the whites practiced this exclusion under the garb of colour. There are subtle hints in the novel that apartheid was practiced by the white man in Nigeria (NLE, 2010, p. 3, 5).

One of the key differences between Ibo traditions and Christianity is the reverence of the ancestors. Ibo traditions laid great stress on the reverence of the ancestors, Christianity did not allow any reverence to the ancestors because the God did not have any family ties himself. That is what Ibos ask the missionaries:

"You told us with your own mouth that there was one God. Now, you talk about his son. He must have a wife, then" (TFA, 2001, p.107).

The question is logical, but it is ignored by the missionaries because they do not have any answer to it. Their commandment is not to maintain family ties, rather it is to severe them: "Blessed is he who forsakes his father and his mother for my sake" (TFA, 2001, p. 112).

On the other hand, Obi's grandfather was distressed at the loss of their traditional practice of worshipping the ancestors. Achebe brings out his psychological crisis:

To abandon the gods of one's father and go about a lot of effeminate men clucking like old hens was the very depth of abomination. Suppose he died all his male children decided to follow Nwoye's steps and abandon their ancestors? Oknokwo felt a cold shudder run through him at the terrible prospect of annihilation. He saw himself and his father crowding round their ancestral shrine waiting in vain for worship and sacrifice and finding nothing but ashes of by gone days, and his children the while praying to the white man's god. (TFA, 2001, p. 112)

The fate of Ogbuebi Okonkwo is not known, but Christianity does estrange Obi to his family and he fails to attend even his mother's funeral.

Whatever could not be accomplished by white man's religion was accomplished by the white man's language. This was also accomplished by the missionaries who accompanied the colonial armies. Ngugi WaThiongo deliberates on the process:

For colonialism this involved two aspects of same process: the destruction or the deliberate undervaluing of a people's culture, their art, dances, religions, history, geography, education, orature and literature, and the conscious elevation of the language of the colonizer. The domination of a people's language by the languages of the colonising nations was crucial to the domination of the mental universe of the colonized. (1986, p. 16)

The Ibo culture was oral, but the missionaries stressed that the "leaders of the land in future would be men and women who had learnt to read and write" (TFA, 2001, p. 132). It was during the times of Ogbuefi Okonkwo that the missionaries started conditioning the Ibos about the superiority of their language and writing system. No Longer at Ease shows how successful they were in obliterating their culture by imposing English on the Nigerians. Obi's father develops a strong fascination for the books, which shows his strong attachment to the whites and their culture:

Mr. Okonkwo believed utterly and completely in the things of the white man. And the greatest symbol of the white man's power was the written word, or better still the printed word. (2010, p.100) 
Isaac Okonkwo developed a strong liking for the books because they represented the "uli that never fades" (2010, p.101). In other words it represents the power of the whites. Chinua Achebe himself mentioned in an interview that the Ibos got attracted to the whites because they were powerful:

The Ibo saw the Europeans and the power they had and listened to what they preached, they put two and two together, and said you know, these people are so powerful, there must be something in what they believe. (Bonneti, 1989, p. 64-65)

The Ibos were converted to Christianity because they were impressed by the power of the colonizers. However, Achebe stresses on another quality of the Ibos: "The Ibo never accepted anything which is rigid and final and absolute" (Bonneti, 1989, p. 65). That is why there are people like Ogbuebi Odogwu who go to church once a year but have not converted because Christianity did not allow any questions: "His only Criticism of Christian service was that the congregation was denied the right to reply to the sermon" (NLE, 2010, p. 42).

It was the intellectual prowess of Achebe that he was able to see through the colonial design. Only a few intellectuals were able to observe the changes that were taking place in their societies. Ordinary Nigerians were in awe of the white man and his capabilities:

"If you see a white man, take off your hat for him. The only thing he cannot do is mould a human being" (NLE, 2010, p. 11).

The negative impacts of colonialism like cropping up of slums in Lagos (NLE, 2010, p. 10) are everywhere, but an ordinary Nigerian is oblivious to it. They have been conditioned to believe that the white man is very powerful and doing jobs for him brings power and money. Achebe makes it clear through the example of the soldiers who have fought for the British in world war:

Those soldiers were heroes who had seen the great world. They spoke of Abyssinia, Egypt, Palestine, Burma and so on. Some of them had been village ne'er-do-wells, but now they were heroes. They had bags and bags of money and the villagers sat at their feet to listen to their stories. One of them went regularly to a market in the neighboring village and helped himself to whatever he liked. He went in full uniform, breaking the earth with his boots, and no one dared touch him. It was said that if you touched a soldier, Government would deal with you. (NLE, 2010, p. 10)

Thus, the ordinary Nigerians were under the impression that colonial servants are protected by the government and were paid huge seems of money. So the ordinary Nigerians were conditioned to become subservient to colonial machinery because it was the only way in colonial Nigeria to become rich and powerful.

Modern myths were perpetrated that the whites have technology to make ordinary people very powerful: "Besides, soldiers were as strong as lions because of the injections they were given in the army" (NLE, 2010, p. 10). Nigerians were not only conditioned to believe that whites were economically and technologically superior, but also morally superior. Nigerians were conditioned to believe that the whites were not corrupt (NLE, 2010, p 27), but Albert Memmi has made clear that the presence of whites in Nigeria or any other colony was part of corruption:

A foreigner, having come to a land by accidents of history, he has succeeded not merely in creating a place for himself but also in taking away that of inhabitant, granting himself astounding privileges to the detriment of those rightfully entitled to them. And this not by Virtue of local laws, which in a certain way legitimize this inequality by tradition, but by upsetting the established rule and substituting his own. (1967, p.9) 
Albert Memmi further calls the colonizer "a privileged being and an illegitimately privileged one; that is a usurper" (1967, p.9).

In fact, Achebe is critical of white institutions. The impacts of colonialism are shown through Obi. The difference between Obi and other individuals of the Ibo community is most obvious. Obi appears as an individual who is alienated and has no sense of community left in him. The other Ibos have a strong feeling of community. In fact, Umuofia Progressive union's move to approve a loan of eight hundred pounds to him to enable his education in England proves disastrous. White man's education alienates him further and he insults his benefactors (NLE, 2010, p. 66), but the Ibos in Lagos stand with him through thick and thin. The Ibos understand the importance of unity:

Our fathers also have saying about the danger of living apart. They say it is the curse of the snake. If all snakes lived together in one place, who would approach them? But they live every one unto himself and so fall easy prey to man. (NLE, 2010, p. 64)

The Ibos in Lagos are not affected by alienation and their insult by Obi. They easily forget all the bad things about Obi and decide to stand with Obi:

They had no illusions about Obi. He was, without doubt a very foolish and self-willed young man. But this was not the time, to go into that. The fox must be chased away first; after that the hen might be warned against wandering into the bush. (NLE, 2010, p. 4-5)

Achebe makes a point through Obi about the importance of cultural settings. His conditioning during the childhood about "heathens" had weakened the sense of community in him and his stay in England further emasculates his cultural ties.

Irele in his study of Achebe's novels rightly comments: "What runs through all this literature is the feeling that it is within our traditional culture that we are happiest most at ease with ourselves, that there is a truest coincidence between us and the world: in other words, that our identity is located" (1992, p.204). The relation between cultural alienation and debilitation of morals is further accentuated by Achebe through the relationship between Obi and his mother. Obi's father has alienated his family from the culture of his ancestors and community. Obi's mother is the only link that exists between him and his ancestral culture. Due to his father's zeal the transmission of Ibo culture has stopped, but little cultural values that are transmitted to Obi are through his mother hidden from his father's eyes. Obi knows that if allowed she would have further nurtured him in their culture:

She was a very devout woman, but Obi used to wonder whether, left to herself, she would not have preferred telling her children the folk stories that her mother had told her. In fact, she used to tell her eldest daughters stories. But that was before Obi was born. She stopped because her husband forbade her to do so. (NLE, 2010, p. 46)

His mother taught him traditional story to tell in the class (NLE, 2010, p. 47).

Achebe further stresses the bond between Obi and his mother through a moving incidence:

He had a rusty razor blade with which he sharpened his pencil or sometimes cut up a grasshopper. One day he forgot this implement in his pocket and it cut his mother's hand very badly when she was washing his clothes on a stone in the stream. (NLE, 2010, p. 60)

The episode is clearly symbolic. Here his mother stands for culture and cutting of her hand shows his estrangement from his culture. His mother's faith in her traditional culture is further stressed 
when she said that she had "lost faith in the European medicine and would like to try a native doctor" (2010, p. 107). Obi's mother is an embodiment of traditional culture for him. In her life time his education may have alienated Obi but he resists all the attempts that are made to bribe him (2010, p.69, 74). He becomes a corrupt man after his mother's death. His mother's death symbolizes the complete estrangement from his culture and morality nurtured by the culture.

Thus, it can be concluded that Achebe's call in the novels is to return back to their own culture. No Longer at Ease is tragic, but it is not a lament; rather it is a celebration that can lead to the liberation of the author's people. Through his novels Achebe has shown the different stages of colonialism; the initial skirmishes between the cultures, then complete enslavement to the invader's culture and then the realization of what imperialism has done to them. Achebe's novels are the outcome of that realization. The novels show that at least some people have realized the impact of colonialism on their society; the other who are still oblivious to the evils of colonialism can realize it after reading such novels. The author stresses that the return is always possible with greater knowledge. Earlier the people knew only about the Ibo culture, but now they know about the white culture also. They can imbibe the good aspects of the white culture and work for the bright future of their country and humanity.

\section{Works Cited:}

Achebe, Chinua. 2001. Things Fall Apart, London: Penguin.

Achebe, Chinua. 2010. No Longer at Ease, London: Penguin.

Babalola, C.A. 1986. A Reconsideration of Achebe's No Longer at Ease. Phylon, 47.2, 139-147.

Balgangadhara, S.N. 2013. “The Heathen in his Blindness..." Asia, West and the Dynamic of Religion. Delhi: Manohar.

Bandele, Biyi. 2001. Introduction. In Chinua Achebe's Things Fall Apart, London: Penguin.

Bonetti, Kay. 1989. An Interview with Chinua Achebe. The Missouri Review, 12.1, 61-83.

Cesaire, Aime. 2010. Discourse on Colonialism. Delhi: Aakar Books.

Espada, Marcos Jimenez De la. 1877. Book of Knowledge. Trans. Sir Clements Markham. London: The Hakluyt Society.

Gikandi, Simon. 2001. Chinua Achebe and the Invention of African Culture. Research in African Literatures, $32.3,3-8$.

Irele, Abiola. 1992. In Praise of Alienation, In V.Y. Mudimbe (ed.), The Surreptious Speech: Presence of Africaine and Politics of Otherness. Chicago: University of Chicago Press.

---. (2001). Homage to Chinua Achebe. Research in African Literatures, 32.3, 1-2.

Keesing, Roger M. 1974. Theories of Culture. Annual Review of Anthropology 3, 73-97, JSTOR.

Memmi, Albert. 1967. The Colonizer and the Colonized. Trans. Howard Greenfield. Boston: Beacon.

Merriam, Allen H. 1988. Literature as Window: Developing Interracial Understanding through Fiction. Journal of Black Studies, 1, 61-69.

Page, Jake. 2003. In the Hands of the Great Spirit. New York: Free press

Pal, Virender. 2010. Poles Apart: portrayal of Africa in the Novels of Chinua Achebe's Things Fall Apart and Joseph Conrad's Heart of Darkness. Notions 3, 155-162.

Rogers, Philip. 1983. "No Longer at Ease": Chinua Achebe's "Heart of Whiteness," Research in African Literatures, 14.2, 165-183.

Thiongo, Ngugi Wa. 1986. Decolonising the Mind, Delhi: Book Land Publishing Co.

Virender Pal Teaches English at University College, Kurukshetra University Kurukshetra. He has done his Ph.D. on Australian Aboriginal literature. He is the author of several academic papers and has completed a UGC sponsored minor project on "Debunking Dalit Stereotypes: A Study of U.R. Ananthamurthy's Novels." His interests include Native literature and Indian literature. 